\title{
Why the U.S. Government Failed to Anticipate the Rwandan Genocide of 1994: Lessons for Early Warning and Prevention
}

Matthew Levinger

George Washington University

Follow this and additional works at: https://digitalcommons.usf.edu/gsp

\section{Recommended Citation}

Levinger, Matthew (2016) "Why the U.S. Government Failed to Anticipate the Rwandan Genocide of 1994: Lessons for Early Warning and Prevention," Genocide Studies and Prevention: An International Journal:

Vol. 9: Iss. 3: 33-58.

DOI:

http://dx.doi.org/10.5038/1911-9933.9.3.1362

Available at: https://digitalcommons.usf.edu/gsp/vol9/iss3/6

This Articles is brought to you for free and open access by the Open Access Journals at Digital Commons @ University of South Florida. It has been accepted for inclusion in Genocide Studies and Prevention: An International Journal by an authorized editor of Digital Commons @ University of South Florida. For more information, please contact digitalcommons@usf.edu. 


\title{
Why the U.S. Government Failed to Anticipate the Rwandan Genocide of 1994: Lessons for Early Warning and Prevention
}

\author{
Matthew Levinger \\ George Washington University \\ Washington, DC, USA
}

\begin{abstract}
During the months leading up to the Rwandan genocide of 1994, cognitive biases obstructed the capacity of U.S. government analysts and policymakers to anticipate mass violence against the country's Tutsi minority. Drawing on declassified U.S. government documents and on interviews with key current and former officials, this essay shows that most U.S. government reporting on Rwanda before April 1994 utilized a faulty cognitive frame that failed to differentiate between threats of civil war and genocide. Because U.S. officials framed the crisis in Rwanda as a potential civil war, they underestimated the virulence of the threat to Tutsi civilians and discounted the risk of catastrophic violence. The "civil war frame" also justified rigid U.S. policy guidance that may have exacerbated ethnic and political conflicts in Rwanda on the eve of the genocide. The phenomenon of faulty cognitive framing remains a challenge for contemporary atrocity prevention and response efforts toward countries including Libya and South Sudan.
\end{abstract}

Keywords: Rwanda, genocide prevention, intelligence analysis, peace negotiations, framing, cognitive biases, Arusha Accords, Libya, South Sudan, Syria

The hundred-day bloodletting in Rwanda from April through July 1994, which took more than 500,000 lives, represented one of the moral low points of the twentieth century. In a speech of March 1998, delivered on the tarmac at Kigali airport, U.S. President Bill Clinton acknowledged that the "international community, together with nations in Africa, must bear its share of responsibility for this tragedy." Clinton declared that "all over the world there were people like me sitting in offices, day after day after day, who did not fully appreciate the depth and the speed with which you were being engulfed by this unimaginable terror."1

Most scholarship on the Rwandan genocide has rejected such claims that international observers did not know, or "did not fully appreciate," what was going on in Rwanda before and during the genocide. As Samantha Power observes in her book "A Problem from Hell": America and the Age of Genocide:

Ahead of the April 6 plane crash [in Kigali that killed Rwandan President Juvenal Habyarimana and triggered the genocide], the United States ignored extensive early warnings about imminent mass violence. It denied Belgian requests to reinforce the peacekeeping mission. When the massacres started, not only did the Clinton administration not send troops to contest the slaughter, but it refused countless other options. President Clinton did not convene a single meeting of his senior foreign policy advisers to discuss U.S. options for Rwanda. ${ }^{2}$

Many commentators have asserted that, during the months leading up to April 1994, international observers grasped clearly the gravity and imminence of the threat of genocide in Rwanda. The Organization of African Unity (OAU) official inquiry, Rwanda: The Preventable Genocide, is typical in this regard:

There can be not an iota of doubt that the international community knew the following: that something terrible was underway in Rwanda, that serious plans were afoot for even more appalling deeds, that these went far beyond routine thuggery, and that the world nevertheless stood by and did nothing.... There were a thousand early warnings that something appalling was about to occur in Rwanda. If not a genocide, it was at least a catastrophe of so great a magnitude that it should command international intervention. ${ }^{3}$

\footnotetext{
${ }^{1}$ Clinton, President Bill. "Address to Genocide Survivors at the Airport in Kigali, Rwanda," 25 March 1998. Available from: http://www.cbsnews.com/news/text-of-clintons-rwanda-speech/ (accessed 14 January 2016).

2 Power, Samantha. 2002."A Problem from Hell": America and the Age of Genocide. New York: Basic Books, 334-35.

${ }^{3}$ Organization of African Unity (OAU) International Panel of Eminent Personalities, Rwanda: The Preventable Genocide,
} 
According to this line of analysis, the key obstacle to effective preventive action was not the failure to comprehend the danger, but rather the inability of working-level diplomats and intelligence analysts to draw the attention of senior policymakers to the crisis, and-after April 6-the lack of "political will" for a robust response to the genocide. ${ }^{4}$ In Power's words:

Simply put, American leaders did not act because they did not want to. They believed that genocide was wrong, but they were not prepared to invest the military, financial, diplomatic, or domestic political capital needed to stop it. ${ }^{5}$

A few scholars, however, have argued that the absence of knowledge-or perhaps the presence of the wrong kind of knowledge-about the unfolding events in Rwanda did indeed play a critical role in shaping responses to the genocide by the U.S. government and other international actors. One of the earliest retrospective inquiries into this topic, published in 1996 by the OECD Steering Committee for Joint Evaluation of Emergency Assistance to Rwanda, concluded that on the eve of the genocide:

There were significant signs that forces in Rwanda were preparing the climate and structures for genocide and political assassinations. However, people both in the region and the broader international community ignored, discounted or misinterpreted the significance of these signs, thereby not only indicating an unwillingness to intervene, but communicating that unwillingness to those who were planning genocide. ${ }^{6}$

According to the Steering Committee, international policymakers' perceptions of the situation in Rwanda on the eve of the genocide were colored by two events of the previous year. The first of these events was the signing of the Arusha Accords of August 1993, which had set the terms of a peace settlement between Rwanda's Hutu ruling coalition and the Tutsi insurgency of the Rwandan

7 July 2000, Ch. 9, par. 1 and 16, Available from: http://www.peaceau.org/en/article/rwanda-the-preventable-genocide (accessed 14 January 2016).

${ }^{4}$ See for example Prunier, Gérard. 1995. The Rwanda Crisis: History of a Genocide. New York: Columbia University Press; Keane, Fergal. 1995. Season of Blood: A Rwandan Journey. London: Viking; Castonguay, Jacques. 1998. Les casques bleus au Rwanda. Paris: Harmattan; Des Forges, Alison. 1999. "Leave None to Tell the Story": Genocide in Rwanda. New York: Human Rights Watch; Adelman, Howard and Astri Suhrke.1999. The Path of a Genocide: The Rwanda Crisis from Uganda to Zaire. New Brunswick, NJ: Transaction Publishers; Melvern, Linda. 2000. A People Betrayed: The Role of the West in Rwanda's Genocide. London: Zed Books; Melvern, Linda. 2004. Conspiracy to Murder: The Rwandan Genocide. London: Verso; Gourevitch, Philip. 1998. We Wish to Inform You that Tomorrow We Will Be Killed with Our Families: Stories from Rwanda. New York: Farrar, Straus, and Giroux; Grünfeld, Fred and Anke Huijboom. 2007. The Failure to Prevent Genocide in Rwanda: The Role of Bystanders. Leiden: Koninklijke Brill NV; Power, A Problem from Hell; Leader, Joyce E. 2001. Rwanda's Struggle for Democracy and Peace, 1991-1994. Washington, D.C: The Fund for Peace; Dallaire, Roméo. 2003. Shake Hands with the Devil: The Failure of Humanity in Rwanda. Toronto: Random House Canada; Marchal, Luc. 2001. Rwanda: La descente aux enfers: témoignage d'un peacekeeper, décembre 1993-avril 1994. Brussels: Editions Labor; Feil, Scott. 1998. Preventing Genocide: How the Early Use of Force Might Have Succeeded in Rwanda, Carnegie Commission on Preventing Deadly Conflict. New York: Carnegie Corporation of New York; Straus, Scott. 2006. The Order of Genocide: Race, Power, and War in Rwanda. Ithaca: Cornell University Press; Official inquiries into international responses to the genocide include: the UN Report of The Independent Inquiry into the Actions of the United Nations During the 1994 Genocide in Rwanda and Statement of the SecretaryGeneral on Receiving the Report of the Independent Inquiry into the Actions of the United Nations During the 1994 Genocide in Rwanda, 15 December 1999, available from: http://www.un.org/Docs/journal/asp/ws.asp?m=S/1999/1257 (accessed 14 January 2015), France's Rapport d'Information sur les opérations militaires menées par la France, d'autres pays et l'ONU au Rwanda entre 1990 et 1994, available from: http://www.assemblee-nationale.fr/dossiers/rwanda/r1271.asp (accessed 14 January 2016); the report of the Belgian Parliamentary commission of inquiry regarding the events in Rwanda, 6 December 1997, available from: http://www.senate.be/english/rwanda.html (accessed 14 January 2016); and the Organization of African Unity's report of the International Panel of Eminent Personalities, Rwanda: The Preventable Genocide.

${ }^{5}$ Power, Samantha. A Problem from Hell, 508. At a 2014 conference co-sponsored by the U.S. Holocaust Memorial Museum and the Hague Institute for Global Justice, many of the speakers reiterated the view that Western diplomats and other international observers familiar with Rwanda fully recognized the risks of genocide in the country. See Colum Lynch, "Exclusive: Rwanda Revisited," Foreign Policy, 5 April 2015. Available from: http://foreignpolicy.com/2015/04/05/rwandarevisited-genocide-united-states-state-department/ (accessed 12 January 2016).

${ }^{6}$ Eriksson, John et al. 1996. The International Response to Conflict and Genocide: Lessons from the Rwanda Experience, Synthesis Report. Copenhagen: OECD Steering Committee of the Joint Evaluation of Emergency Assistance to Rwanda, March, 9. 
Patriotic Front (RPF); the second was the disastrous "Blackhawk Down" incident of October 1993, which had resulted in the deaths of eighteen U.S. Special Forces soldiers in Somalia, provoking fears among American political leaders concerning the dangers of UN peacekeeping missions in Africa:

There existed an internal predisposition on the part of a number of the key actors to deny the possibility of genocide because facing the consequences might have required them to alter their course of action. The mesmerization with the success of Arusha and the failure of Somalia together cast long shadows and distorted an objective analysis of Rwanda. ${ }^{7}$

This emphasis on the cognitive biases of international actors is also found in Michael Barnett's book Eyewitness to a Genocide, which recounts the story of the internal struggles within the United Nations about how to respond to the Rwandan genocide. Barnett emphasizes that the bureaucratic culture of the UN limited the capacity of its officials to perceive events in Rwanda clearly:

Government officials and UN staff came to know Rwanda as members of bureaucracies; the bureaucratic culture situated and defined their knowledge, informed their goals and desires, shaped what constituted appropriate and inappropriate behavior, distinguished acceptable from unacceptable consequences, and helped determine right from wrong. ${ }^{8}$

During the initial weeks after the outbreak of the genocide, Barnett writes, UN Security Council officials "were operating under the influence of uncertainty and organizationally scripted descriptions of the violence as a civil war with unfortunate civilian killings, not a prelude to genocide." ${ }^{\prime 9}$

This essay revisits the debate over whether the international response to the Rwandan genocide was hampered principally by failures of political will, or by failures of comprehension as well. I address the question of how U.S. government officials analyzed the crisis in Rwanda during the months leading up to the genocide-and whether there may have been missed opportunities for effective preventive action that could have averted mass violence.

Although the U.S. government was not the only, nor even the most heavily invested, external power involved in the Rwanda crisis, it played a key role in shaping international responses to the events that preceded the genocide. U.S. diplomats actively sought to end the war that had begun in October 1990 with the invasion of a Tutsi exile army from Uganda, and the U.S. helped broker the Arusha Accords of August 1993. Even more important, as the only superpower left standing after the collapse of the Soviet Union, the U.S. dominated discussions over how to redefine not only its own foreign policy objectives, but also those of its NATO allies and the United Nations, vis-à-vis political developments in Africa.

This paper limits its focus to U.S. government policy toward Rwanda before April 6, 1994, excluding from consideration the question of how U.S. officials responded to the genocide after it had begun. It draws on declassified U.S. government documents, obtained through Freedom of Information Act requests by the National Security Archive at the George Washington University, and on retrospective interviews with key working-level U.S. officials who were involved in formulating and implementing U.S. policy toward Central Africa from 1990 through the eve of the genocide in April 1994.

\footnotetext{
${ }^{7}$ Ibid, 19. See also Suhrke, Astri and Bruce Jones. 2000. "Preventive Diplomacy in Rwanda: Failure to Act or Failure of Actions?" in Opportunities Missed, Opportunities Seized: Preventive Diplomacy in the Post-Cold War World. Edited by Bruce Jentleson. Lanham, MD: Rowman \& Littlefield, 241. "The failure to recognize the transformation of the conflict from civil war to genocide and to anticipate the escalation in victims and, equally, the failure to possibly nip the genocide in the bud at two points in time, constitute the most critical missed opportunities of the Rwanda case."

${ }^{8}$ Barnett, Michael N. 2002. Eyewitness to a Genocide: The United Nations and Rwanda, Ithaca: Cornell University Press, 7.

${ }^{9} \mathrm{Ibid}, 14$. Gregory Brazeal echoes Barnett's arguments, citing the work of Graham Allison and Philip Zelikow on bureaucratic decision-making processes: 1999. Essence of Decision: Explaining the Cuban Missile Crisis, $2^{\text {nd }}$ edition, New York: Addison-Wesley, 4-6. According to Brazeal, responses to genocide by the U.S. government "follow standardized routines, bureaucrats operate according to a 'logic of appropriateness' rather than a 'logic of consequence,' and seemingly irrational results often follow when a bureaucracy is confronted with a problem for which it has no preset response."
} 
Several key findings emerge from this research. Perhaps most strikingly, I conclude that before April 1994, virtually no U.S. diplomats or intelligence analysts working on Central Africa anticipated the scope of the violence that erupted that month. Their worst-case scenarios generally envisioned the resumption of a war between the Hutu-dominated government and the Tutsi Rwandan Patriotic Front resulting in tens of thousands of deaths-more than an order of magnitude less than the actual toll of the genocide. This near-universal misperception of the nature and scope of the threat had fatal consequences for Rwanda's Tutsi.

Two key factors inhibited the capacity of U.S. government analysts and policymakers to comprehend and respond to the imminent catastrophe brewing in Rwanda:

- The use of a faulty cognitive frame that failed to differentiate between threats of civil war and genocide, leading U.S. officials to underestimate the virulence of the threat to Tutsi civilians.

- The adoption of rigid policy guidance stressing the need to achieve a formal power-sharing agreement for Rwanda-and the continuing insistence on staying this diplomatic course despite indications that the implementation of the power-sharing arrangement mandated by the Arusha Accords would exacerbate rather than alleviate the conflicts between rival factions in Rwanda.

After assessing the impact of these factors on U.S. intelligence analysis and diplomacy toward Rwanda, the paper examines the policy implications of this case study. It concludes by discussing the continuing relevance of the lessons of Rwanda for U.S. and international responses to contemporary threats of genocide and mass atrocities.

\section{Rwanda on the Brink of Genocide, 1990-1993}

In October 1993, less than a week after the deaths of 18 U.S. soldiers in the Blackhawk Down incident in Somalia, President Juvenal Habyarimana of Rwanda visited Washington, D.C. to meet with Secretary of State Warren Christopher and other top U.S. government officials. A report published in March 1993 by an international commission of inquiry had accused Habyarimana and his entourage of sponsoring a "deliberate policy" aimed at "inciting Rwandans to hate and attack each other," and of permitting extremist militias to "terrorize people in many parts of the country with no effective reaction from the officials responsible to public security."10 In August 1993, the UN Special Rapporteur on Summary, Arbitrary, and Extrajudicial Executions had issued a report that largely confirmed this commission's findings, concluding that the UN Genocide Convention "might ... be considered to apply to" the massacres committed over the past three years, which had claimed the lives of more than 2,000 Tutsi. ${ }^{11}$

But, in meeting with Habyarimana that October, Secretary Christopher expressed no concerns about human rights abuses by the Rwandan regime. Instead he applauded the Rwandan president for his "great courage" in having signed the Arusha Accords of August 1993, which had settled a three-year war between the Hutu-dominated Rwandan government and the Rwandan Patriotic Front (RPF), an insurgency of expatriate Tutsi who had lived as refugees in Uganda. Christopher "expressed...satisfaction" with the recent UN Security Council vote to create a Rwanda peacekeeping mission, and he articulated his hope that the peacekeepers would "be very effective" in implementing the Accords. ${ }^{12}$

\footnotetext{
${ }^{10}$ Report of the International Commission on Human Rights Abuses in Rwanda since October 1, 1990, March 1993. Available from: https://www.hrw.org/report/1993/03/01/report-international-commission-investigation-human-rights-violations-rwanda (accessed 14 January 2016).

${ }^{11}$ OAU Report of the International Panel of Eminent Personalities, Ch. 9, p. 64; United Nations Economic and Social Council, Rwanda: The Preventable Genocide, "Report by Mr. B. W. Ndiaye, Special Rapporteur, on his mission to Rwanda from 8 to 17 April 1993," 11 August 1993, E/CN.4/1994/7/Add. 1, 22-23.

${ }^{12}$ U.S. Department of State, cable State 313040, "President Habyarimana and Secretary Christopher Discuss Peace Process and Challenges Ahead," 14 October 1993, Rwanda Genocide Collection (compiled 1998-2003), National Security Archive, Washington, DC, available from: http://nsarchive.gwu.edu/NSAEBB/NSAEBB117/Rw27.pdf (accessed 14 January 2016).
} 
Christopher's optimism reflected the views expressed in other State Department policy papers and cable traffic from this period. In June 1993, nine months before the outbreak of genocide, a policy memorandum by Assistant Secretary of State for African Affairs George Moose had described "the reconciliation process" in Rwanda as one of six "realizable goals" for U.S. policy toward Africa in the coming year. "Real progress has been registered," the memo declared. "Prospects are good that Rwanda, a volatile, heavily populated country with a history of extreme ethnic violence, can move into nation-building during the next year."13

In late January 1994, the State Department released its annual Country Report on Human Rights Practices for Rwanda in 1993. The report concluded:

Human rights abuses that plagued the first quarter of 1993 diminished considerably as the peace process progressed... Those abuses stemmed from dissatisfaction on the part of the former sole party, the National Revolutionary Movement for Development (MRND), over the power-sharing arrangement agreed to on January 9 between the multiparty Government and the RPF. ${ }^{14}$

As late as 1 April 1994-six days before the genocide erupted in Kigali-the new U.S. Ambassador to Rwanda, David Rawson, sent a reporting cable to Washington expressing cautious optimism about the political situation in Rwanda, tinged by concern about a possible return to war:

A round of Good Friday calls to observers, the UN and key players suggests that the sides are inching towards each other, but afraid to make the final offer. Many observers believe the installation of institutions will have to await the Arusha summit on Burundi...Our major fear is that the relative calm which has characterized Kigali the last couple of weeks will not hold until then. I have urged all my interlocutors to use every influence at their disposal to encourage calm as we approach this last turn on the course. ${ }^{15}$

The war of 1990-1993 was the outgrowth of a long and bitter polarization of relations between Rwanda's majority Hutu and minority Tutsi ethnic groups. In the pre-colonial era, the rulers had been drawn from the pastoralist Tutsi, rather than the agriculturalist Hutu, but these ethnic distinctions had been fluid and permeable. Under German colonial rule beginning in the 1880s, and especially after Belgium seized control of Rwanda after World War I, the distinction between Hutu and Tutsi became hardened as the Europeans redefined these essentially social categories in racial terms. German and Belgian colonial administrators relied on Tutsi surrogates to rule Rwanda, viewing the Tutsi as an aristocratic race with Caucasoid features, and in the 1920s the Belgian administrators issued racial identity cards that permanently fixed Rwandans' ethnic identities.

The Hutu emancipation movement of the late 1950s, led by Grégoire Kayibanda, represented a rebellion against Tutsi social domination as well as Belgian colonial rule. From the onset of the independence struggle in 1959 through the immediate aftermath of Rwandan independence in 1962, more than 20,000 people died in political violence and 150,000-perhaps half of Rwanda's Tutsi population-fled to neighboring countries including Uganda and Burundi.

Neighboring Burundi, whose population had an ethnic composition similar to Rwanda'sbut where the minority Tutsi ruled the country after independence-also experienced massive intercommunal violence during this era. In 1972, between 100,000 and 300,000 Burundian Hutu were massacred, and thousands of Hutu refugees fled to Rwanda. Taking advantage of the ensuing

\footnotetext{
${ }^{13}$ U.S. Department of State, Information Memorandum from George E. Moose through Mr. Tarnoff to the Secretary, "The African Agenda During the Next Twelve Months: Realizable Goals and Perceived Pitfalls", 18 June 1993, Rwanda Genocide Collection (compiled 1998-2003), National Security Archive, Washington, DC.

${ }^{14}$ U.S. Department of State, "Rwanda Human Rights Practices, 1993," in Country Reports on Human Rights Practices for 1993, 31 January1994, Rwanda Genocide Collection (compiled 1998-2003), National Security Archive, Washington, DC.

${ }^{15}$ U.S. Department of State, cable Kigali 01458, “Negotiations Slide Into Long Weekend," 1 April 1994, Rwanda Genocide Collection (compiled 1998-2003), National Security Archive, Washington, DC. Available from: http://nsarchive.gwu.edu/ NSAEBB/NSAEBB117/Rw02.pdf (accessed 14 January 2016).
} 
chaos, Rwandan army Maj. Gen. Juvenal Habyarimana, a Belgian-trained paratrooper from Northern Rwanda, overthrew President Kayibanda (who had favored the interests of Southern Hutus) in 1973. For the next eighteen years, Habyarimana presided over a stable, autocratic, and increasingly ossified regime in which a Northern Hutu elite maintained its monopoly on power. ${ }^{16}$

In 1990, this regime began to unravel. Under pressure from France and other Western aid donors, Habyarimana announced a program of political reforms in July 1990. These reforms included the transition to a multi-party system by 1992, a referendum on a national political charter by June 1991, the end of compulsory membership in his National Revolutionary Movement for Development (MRND) party, the end of ethnic identification on national identity cards, and the peaceful return of refugees. The issue of refugee return was particularly problematic. By 1990, more than 400,000 Rwandan Tutsi refugees were living in Uganda, Burundi, and Tanzania, and the host governments were placing increasing pressure on these refugee communities. But as the most densely populated country in Africa, Rwanda was ill-equipped to absorb a large influx of repatriated refugees, especially in light of the economic hardship caused by the economic austerity program imposed on Rwanda by the International Monetary Fund and by the collapse of global commodity prices during the early 1990s. Habyarimana's democratization program extended no political rights to Rwandan Tutsi living as refugees outside the country's borders.

On 1 October 1990, approximately 2,000 Rwandan Patriotic Front (RPF) rebels, mainly Rwandan Tutsi refugees serving in Uganda's National Resistance Army, invaded northeast Rwanda from Uganda. With French and Belgian military assistance, Rwandan government forces halted the initial RPF assault. But the U.S. and other donor governments recognized the intractable nature of the conflict and pressed Habyarimana toward negotiations to reach a power-sharing agreement. In the summer of 1991, Habyarimana set forth a new constitution in order to effect political reforms, the national assembly passed a law allowing the formation of political parties, and shortly thereafter five parties registered with the government and began meetings and demonstrations. In early 1992, hard-line members of the president's party founded a Hutu-supremacist party, the Coalition for the Defense of the Republic (CDR), which began lobbying for inclusion in the government. Under pressure from Western donors, in April 1992 Habyarimana named a prime minister from the MDR, the primary opposition party, who then formed a five-party coalition government that limited Habyarimana's power over routine governmental affairs.

In peace talks hosted by Tanzania and attended by American, French, and other international representatives, the transitional government concluded several protocols with RPF representatives collectively known as the Arusha Accords, which were signed by Habyarimana and RPF Chairman Alexis Kanyarengwe in August 1993. The Accords stipulated the establishment of a 22-month broadbased transitional government (BBTG) within 37 days; elections by the end of 1995; the return of exiles, refugees and displaced persons; the integration of FAR and RPF forces; the integration and reduction of the Presidential Guard and other elite forces; and a Neutral International Force (NIF) to maintain peace. But African leaders witnessing the signing were skeptical about the viability of the agreement, and there was no celebration in Kigali. Almost immediately, the Accords' transition process deadlocked, as the various players presented slates of ministerial candidates and maneuvered for position and influence. ${ }^{17}$

Even as the rival factions in Rwanda jockeyed for advantage, the member states of the UN Security Council in New York locked horns over the establishment of the NIF. The Arusha Accords had stipulated that the NIF would carry out a wide range of security tasks, including guaranteeing the overall security of the country, maintaining law and order, tracking arms caches and neutralizing armed gangs throughout the country, and determining security parameters for Kigali with the objective of making it a neutral zone. Under pressure from the U.S. and other member states, the Security Council scaled back both the size and the mandate of the United Nations Assistance Mission in Rwanda (UNAMIR), authorizing a force of 2,548 peacekeepers charged with the responsibilities to "contribute to the security of the city of Kigali inter alia within

\footnotetext{
${ }^{16}$ OAU International Panel of Eminent Personalities, Rwanda: The Preventable Genocide, Ch. 8, "The Arusha Peace Process," 15-33.

${ }^{17}$ Ibid, 34-53; Suhrke and Jones, "Preventive Diplomacy in Rwanda."
} 
a weapons-secure area established by the parties in and around the city," to "monitor observance of the cease-fire agreement," and to "monitor the security situation during the final period of the transitional government's mandate, leading up to the elections." ${ }^{\prime 18}$

In October 1993, before the broad-based transitional government could be established in Rwanda, neighboring Burundi's first elected Hutu president was assassinated by Tutsi military officers. The subsequent two months witnessed a massive bloodletting in which 30,000 to 50,000 Burundian Hutu and Tutsi died in intercommunal violence and 250,000 refugees fled the country. The massacres in Burundi eviscerated what little trust and good will remained between rival Hutu and Tutsi political factions in Rwanda, dealing a fatal blow to the already shaky prospects for the implementation of the Arusha Accords.

\section{The Limits of Foreknowledge: U.S. Conflict Analysis on the Eve of Genocide}

Proponents of the view that U.S. officials surely must have known about the impending genocide have ample ammunition to support their claims. Various diplomats and other international observers had urgently warned of the threat of violence in Rwanda. Canadian law professor Professor William Schabas, a member of the International Commission of Inquiry that visited Rwanda in January 1993, describes the political climate that he and the other members of the Commission encountered:

[F]aced with convincing evidence of mass killings (i.e., tens to hundreds at a time) of Tutsis, accompanied by public incitement whose source could be traced to the highest levels of the ruling oligarchy, the word "genocide" sprang inexorably to our lips.... In a press release issued the day after our departure from Rwanda, we spoke of genocide and warned of the abyss into which the country was heading. ${ }^{19}$

On 11 January 1994, three months before the genocide erupted, the Force Commander of the UN Mission in Rwanda (UNAMIR), Maj. Gen. Romeo Dallaire, faxed UN headquarters in New York to relay information from an informant who worked as a trainer for the President's party militia. After providing details of the militia's direct connections to the President's party and the Rwandan Army, Dallaire's informant reported: "Since UNAMIR mandate he has been ordered to register all Tutsi in Kigali. He suspects it is for their extermination. Example he gave was that in 20 minutes his personnel could kill up to 1000 Tutsis." 20

The following month, Dallaire reported that time was "running out for political discussions" and "any spark on the security side could possibly have catastrophic consequences."21 Following the assassination of two leading government officials in late February, Jacques-Roger Booh-Booh, the UN Special Representative of the Secretary-General in Rwanda, declared that the "general situation is observed to be explosive."22 In a letter to the UN Security Council, the Belgian Foreign Ministry urged that the peacekeeping force in Rwanda be reinforced. It warned, "The political assassinations, the ensuing unrest, and the worsening of the climate of safety, could well lead to

\footnotetext{
${ }^{18}$ Hilaire, Max. 2015. Waging Peace: The United Nations Security Council and Transnational Armed Conflicts. Berlin: Logos Verlag, 70-72; UN Security Council Resolution 872, October 5, 1993. Available from: http://nsarchive.gwu.edu/NSAEBB/ NSAEBB452/docs/doc01.pdf (accessed 14 January 2016).

${ }^{19}$ Schabas, William A. 2000. Genocide in International Law. Cambridge: Cambridge University Press, x.

${ }^{20}$ Facsimile from Maj. Gen. Romeo Dallaire, Force Commander, United Nations Assistance Mission for Rwanda, to Maj. Gen. Maurice Baril, United Nations Department of Peacekeeping Operations, "Request for Protection for Informant," 11 January 1994. See also U.S. Holocaust Memorial Museum, "The Genocide Fax," 2014. Available from: http://www.ushmm. org/confront-genocide/cases/rwanda/turning-points/genocide-fax-part-i (accessed 14 January 2016).

${ }^{21}$ Bloomfield, Sara J. and Michael Abramowitz, "Don't Assume that the Rwandan Genocide Couldn't Happen Today," New Republic, 7 April 2014. Available from: http://www.newrepublic.com/article/117285/rwanda-genocide-20-yearanniversary-what-have-we-learned: (accessed 14 January 2016).

${ }^{22}$ Booh-Booh, Jacques-Roger. Situation Report of 23 February 1994. In Jake Freyer and Emily Willard, editors, “Sitreps Detail Rwanda's Descent into Genocide 1994: Complete Collection of Peacekeepers' Situation Reports from Rwanda to UN Headquarters in New York," National Security Archive Electronic Briefing Book No. 466, 7 April 2014. Available from: http://www2.gwu.edu/ nsarchiv/NSAEBB/NSAEBB466/ (accessed 14 January 2016).
} 
a new bloodbath," and expressed concern that the Belgian peacekeepers could become "passive witnesses to genocide in Rwanda." 23

But most U.S. government diplomatic reporting and intelligence analysis on Rwanda lacked this sense of urgency. Although a few analysts issued warnings about the potential for mass atrocities, virtually none of the Central Africa experts in the U.S. government anticipated the scope of the impending violence. For example, David Rawson, who became U.S. ambassador to Rwanda in January 1994, had grown up in Burundi as the son of a missionary and was one of the only speakers of Kinyarwanda in the U.S. government. Though Rawson "expected internecine killing, he did not anticipate the scale at which it occurred. 'Nothing in Rwandan culture or history could have led a person to that forecast,' he says. 'Most of us thought that if a war broke out, it would be quick, that these poor people didn't have the resources, the means, to fight a sophisticated war. I couldn't have known that they would do each other in with the most economic means."'24 George Moose, then serving as Assistant Secretary of State for African Affairs, echoes this view: "We were psychologically and imaginatively too limited." 25

For officials at the highest echelons of the U.S. government, the degree of awareness of the situation in Rwanda was far lower. Madeleine Albright, who was the U.S. Ambassador to the United Nations, recalls:

There had been killings in Somalia, Bosnia; just constant attention to a lot of other issues, unfortunately. We did know obviously that there were struggles both in Rwanda and Burundi. There was hope that the Arusha accords would actually have resolved some of the long-term fighting between the Hutus and Tutsis, so I think it was not high on the agenda.... It didn't show up very often in intelligence summaries. There were not very frequent reports about it. ${ }^{26}$

According to Anthony Lake, President Clinton's National Security Adviser from 1993 to 1997, "[T] here was very little attention to what the problem was and how to fix it politically . . . at least at my level." Several days after the genocide erupted on 6 April 1994, Lake attended a meeting at the Pentagon to plan the evacuation of American civilians from Rwanda. At the end of the meeting, he says, "I asked some of the people from the Defense Intelligence Agency, 'So what's going on? Who's killing who? I haven't seen much about this.' Maybe I'd seen something, but hadn't certainly focused on it. And they couldn't tell me." ${ }^{27}$ Likewise, Lieutenant General Wesley Clark, who was then serving as Director of Strategic Plans and Policy for the Department of Defense, "frantically telephoned around the Pentagon for insight into the ethnic dimensions of events in Rwanda" in early April. Clark remembers staff officers asking: "Is it Hutu and Tutsi or Tutu and Hutsi?" 28

To evaluate the quality of U.S. intelligence analysis and diplomatic reporting on Rwanda during the months leading up to the genocide, one must first make clear one's premises about the nature and purpose of conflict analysis and early warning. Many laypeople conceive of intelligence analysis as a kind of crystal ball whose value depends on how accurately it predicts future events. For example, several publications on the Rwanda genocide have asserted that, in early 1994, a CIA analyst predicted that as many as 500,000 people might die there in genocidal violence. ${ }^{29}$ They present this claim as proof that the U.S. government knew that genocide was imminent in Rwanda, and that it should have taken more robust preventive action.

\footnotetext{
${ }^{23}$ Belgian Foreign Ministry, Telex \#64, From MINAFET to DELBELONU, 25 February 1994. Available from: https://www.documentcloud.org/documents/1015806-19940225-gob-bsrr-translation.html\#document/p1/a144308 (accessed 14 January 2016).

${ }^{24}$ Quoted in Power A Problem From Hell, 347-48.

${ }^{25} \mathrm{Ibid}, 348$.

${ }^{26}$ Albright, Madeleine. Interview for PBS Frontline documentary, "Ghosts of Rwanda," 25 February 2004. Available from: http://www.pbs.org/wgbh/pages/frontline/shows/ghosts/interviews/albright.html (accessed 14 January 2016).

${ }^{27}$ Lake, Anthony.Interview for PBS Frontline documentary, “Ghosts of Rwanda," 13 December 2003. Available from: http://www.pbs.org/wgbh/pages/frontline/shows/ghosts/interviews/lake.html (accessed 14 January 2016).

${ }^{28}$ Power, A Problem From Hell, 330.

${ }^{29} \mathrm{Ibid}, 338$; OAU, Rwanda: The Preventable Genocide, chap. 9, p. 5; Des Forges, xxx.
} 
But this line of argumentation presents two difficulties. First, the intelligence report that allegedly predicted half a million deaths may well be apocryphal. Three senior U.S. government analysts - two from the CIA and one from the State Department-who have searched the CIA's classified records have been unable to locate any such document. Nor does such a document appear in the collection of nearly 4,500 declassified U.S. and Canadian diplomatic cables and intelligence reports from between 1990 and 1994 concerning Rwanda that have been obtained by the National Security Archive, an independent institute at the George Washington University, ${ }^{30}$ or in a more recent tranche of declassified documents published by the U.S. Holocaust Memorial Museum in $2014 .{ }^{31}$

The second, more fundamental difficulty with the claim that the CIA predicted the Rwandan genocide lies in the very assumption that intelligence analysis should have the capacity to accurately predict future events. Nassim Taleb, a statistician who studies business risks, points out that there are inherent limitations to humans' capacity to anticipate future catastrophic events. Taleb uses the term "Black Swan" to describe a "random event satisfying the following three properties: large impact, incomputable probabilities, and surprise effect." Because a Black Swan represents a sudden and massive deviation from a normative state "with nothing in the past history of the process ... indicating such possibility," it cannot be reliably predicted. Moreover:

By some vicious dialectic, it is the surprise element that either causes the Black Swan or at least exacerbates its consequences. If there were anything [in past experience] convincing about the need for protection, then agents would have taken preventive or protective actions. These would have either stopped it in its tracks or limited its impact. ${ }^{32}$

One of the most sophisticated Central Africa analysts in the U.S. government in 1994 worked in the State Department's Bureau of Intelligence and Research. An expert on the political dynamics of Rwanda and Burundi, he had a Ph.D. in Conflict Resolution had done extensive research on peace processes in Africa. In his view, the Rwandan genocide meets Taleb's criteria for the Black Swan: "I don't think normal analysis can account for a 'perfect storm.' I still think that if you put good analysts in a room and gave them the pre-94 data they would not come up with genocide on that scale." 33

Indeed, recent historical research by historians including André Guichaoua, as well as findings by the International Criminal Tribunal for Rwanda (ICTR), suggests that the genocide may not have been fully planned in advance. Rather, the violence escalated rapidly in April 1994 as a result of evolving circumstances on the ground and decisions made by key actors in the conflict. ${ }^{34}$

Although it may have been impossible before April 1994 to predict the magnitude of the impending violence in Rwanda, ample evidence existed regarding the ominous nature of the conflict. One curious aspect of international reporting on Rwandan politics during this period is that, in several cases, observers with relatively little personal knowledge of Central Africa recognized the threat of genocide more clearly than seasoned Africa hands in the U.S. government, the United Nations, and other organizations. In 1993, both the International Commission of Inquiry on Violations of Human Rights in Rwanda and B. W. Ndiaye, the UN Special Rapporteur, described the conflict as a potential genocide-though neither predicted the magnitude of the killing. In

\footnotetext{
${ }^{30}$ Rwanda Genocide Collection (compiled 1998-2003), National Security Archive, Washington, DC.

${ }^{31}$ U.S. Holocaust Memorial Museum, "Rwanda: Turning Points," 2014. Available from: http://www.ushmm.org/confrontgenocide/cases/rwanda/turning-points (accessed 14 January 2016).

${ }^{32}$ Taleb, Nassim N. “Rare Events: Why Don't We Understand Them?” (unpublished ms.), Highland Forum 23, Las Vegas, November 2003, 5-6. Available from: http://highlands.vmhost.psu.edu/ reading/docs/blackswan.pdf (accessed 14 January 2016).

${ }^{33}$ U.S. State Department Rwanda-Burundi analyst, interview with the author, March 8, 2007. In The U.S. State Department's Bureau of African Affairs declined the author's request to quote this analyst by name, so he is referred to in subsequent references simply as a U.S. State Department Rwanda analyst.

${ }^{34}$ See for example Guichaoua, André. 2005. Rwanda 1994: Les politiques du genocide à Butare. Paris: Editions Karthala; Guichaoua, André, editor. 1995, Les crises politiques au Burundi et au Rwanda (1993-1994). Lille: Université de Lille 1, Diffusion Karthala.
} 
January 1994, the newly arrived UN force commander in Rwanda, Gen. Dallaire, also warned of the potential for catastrophic violence against Rwandan Tutsis.

U.S. diplomats and analysts witnessed the same danger signs as these other observers but frequently discounted their significance. Ambassador Joyce Leader, who was Deputy Chief of Mission in Embassy Kigali from 1991 to 1994, recalls a series of worrisome events of late 1992 and early 1993:

- The infamous speech of 22 November 1992 by Leon Mugesera, an MRND official in the Northwestern Gisenyi Prefecture (Pres. Habyarimana's home district), denouncing the opposition parties as traitors, condoning summary justice against them, and declaring that the "Tutsi should return to Ethiopia from whence they came ... via the Nyaborongo River" (implying that they should be murdered and their bodies thrown into the river). According to Amb. Leader, Mugesera's message "spread by word of mouth like wildfire throughout the country," and that subsequently, Tutsi employees of the American embassy "were falling asleep at their desks, unable to do their work," because the men were standing guard at night to protect their families from attack.

- A speech by a local official in Gisenyi Prefecture in late December 1992 warning of imminent RPF attacks and advising listeners to "clear the brush" in the forest-i.e. kill Tutsi villagers - "so the RPF would have nowhere to hide."

- The massacres of at least 300 Tutsi in Gisenyi Prefecture in December 1992 and January 1993, which, "though portrayed as spontaneous, ... stopped abruptly during a two to three week period in January when an International Commission on Human Rights was in Rwanda."

- "Daily reports ... about deaths and destruction across northern Rwanda." ${ }^{35}$

Yet the Embassy staff made little systematic effort to investigate these incidents. Joyce Leader recalls: "[W]e knew about the formation and the training of the militia, but we didn't do anything about it, except to talk to people and say that this is unconscionable-you can't do this." ${ }^{36}$ Indeed, diplomatic cables from Embassy Kigali sometimes minimized the significance of the violence in Rwanda. For example, on 16 December 1992, the State Department's Bureau of Human Rights and Humanitarian Affairs transmitted a draft of the 1992 Country Report on Human Rights Practices for Rwanda to Embassy Kigali. The report charged: "In 1992 there were significant human rights abuses, many related to the conflict with the RPF," and that: "Credible reports allege that local officials were involved in widespread ethnic violence in March in which 300 died and 15,000 were displaced." ${ }^{37}$ A week later, Embassy Kigali cabled back to protest these allegations:

We contest the claim of "significant human rights abuses." War, ethnic violence, political violence, terrorism and unchecked assaults are abominations and cause immense human suffering. Can they, however, be classified as human rights abuses when their links to government actions or agents are tenuous, unproven and, indeed, seem to be perpetrated by all sides and not necessarily orchestrated or organized? In Rwanda, all sides are suspect but conclusive evidence is either lacking or ambiguous. We propose:

In 1992 there were human rights abuses in Rwanda, many related to the conflict with the RPF. ${ }^{38}$

\footnotetext{
${ }^{35}$ Leader, Joyce E. Rwanda's Struggle for Democracy and Peace, 22-23.

${ }^{36}$ Leader, Amb. Joyce E. Interview with the author, November 2004.

${ }^{37}$ U.S. State Department, Bureau of Human Rights and Humanitarian Affairs, "Rwanda: Initial Edit of 1992 Country Report on Human Rights Practices," 16 December 1992, 3, Rwanda Genocide Collection (compiled 1998-2003), National Security Archive, Washington, DC.

${ }^{38}$ Embassy Kigali to Secretary of State Washington, “Comments on Initial Edit of 1992 Human Rights Report: Rwanda," 23 December 1993, 3, Rwanda Genocide Collection (compiled 1998-2003), National Security Archive, Washington, DC.
} 
As for the reports published by the International Commission of Inquiry in March 1993 and by the UN Special Rapporteur that August, Embassy Kigali noted duly their assertions, but did not share their sense of alarm. Indeed, the first draft of the Embassy's 1993 Human Rights Country Report for Rwanda, composed that October, asserted: "The peace process that culminated in the August 4 peace accord led to the virtual elimination of the human rights abuses that plagued the country during the first quarter of 1993." ${ }^{39}$ Commenting on a subsequent draft of the Human Rights Report two months later, Embassy Kigali declared of the International Commission of Inquiry:

The group's findings were welcomed by the human rights groups in Rwanda that believe the president and his party are behind all abuses; they documented long-held suspicions. However, the human rights groups that defend Hutus criticized the Commission's work. The Commission's methodology had several weaknesses. ${ }^{40}$

The Embassy did not elaborate on the nature of the weaknesses it perceived in the Commission's report.

During the eighteen months before the genocide, analysts at both the State Department and the Defense Intelligence Agency issued occasional warnings of the potential for mass atrocities in Rwanda. Already in September 1992, the State Department's Bureau of Intelligence and Research (INR) issued a classified report with the chillingly prescient subtitle "The Hutu Right and the Genocide Card." This report pointed out that, historically, when exiled Tutsi had launched crossborder attacks aimed at toppling the Hutu-dominated government, "The Kigali regime-or certainly key elements within it - reacted by killing Tutsis living inside Rwanda." ${ }^{41}$ In February 1993, following the Gisenyi massacres and the subsequent resumption of the RPF offensive in Northern Rwanda, the DIA Weekly Warning Forecast Summary declared: "Renewed warfare could lead to the RPF and government forces participating in 'ethnic cleansing' of their opponents further exacerbating the situation." 42

Despite having invoked the term genocide, the author of the State Department report says that he did not imagine the possibility of the full-scale destruction of Rwanda's Tutsi population:

I was certainly aware of the possibility of something like that happening, of genocidal type killing going on. The thing that I didn't get was the scale of this thing. I think I explicitly said, "Oh you could have like twenty thousand people killed, as occurred in the early sixties, twenty thousand people." It's sort of like, magnify that by ten times or twenty times, or forty times! That took a leap of imagination I just didn't have. ${ }^{43}$

But the majority of U.S. intelligence reporting and diplomatic cables on Rwanda before April 1994 failed to differentiate between the threat of war and genocide. Typical of such reports was the CIA's classified Africa Review of 14 January 1994, which included an item on Rwanda under the heading: "Sub-Saharan Africa: Democratization Chronology." Circulated three days after Gen. Dallaire's alarming fax to UN headquarters about the arms caches in Kigali, this report included no mention of the Dallaire fax (which none of our interviewees reports ever having seen before the genocide), but two brief paragraphs about the renewed mandate of the UN peacekeeping mission to Rwanda and one paragraph on delays in the implementation of the Arusha Accords:

\footnotetext{
39 Embassy Kigali, “1993 Human Rights Report: Rwanda,” Kigali 03613, 4 October 1993, 3, Rwanda Genocide Collection (compiled 1998-2003), National Security Archive, Washington, DC.

${ }^{40}$ Embassy Kigali, “Rwanda: Comments on Initial Edit of 1993 Report on Human Rights Practices," Kigali 04523, 22 December 1993, Rwanda Genocide Collection (compiled 1998-2003), National Security Archive, Washington, DC.

${ }^{41}$ U.S. State Department Rwanda analyst, interview with the author, November 2004.

${ }^{42}$ DIA Weekly Warning Forecast Summary, 10 Feb. 1993, 2, Rwanda Genocide Collection (compiled 1998-2003), National Security Archive, Washington, DC.

${ }^{43}$ U.S. State Department Rwanda analyst, interview with the author, November 2004.
} 
Political bickering ... indefinitely postpones the swearing in of a broad-based transitional cabinet and national assembly as called for by the August 1993 settlement agreement that ended 34 months of fighting between the ethnic Hutu-majority based regime and opposing Tutsi rebels. Any prolonged impasse risks a breakdown of the country's cease-fire. ${ }^{44}$

Apart from the reference to political bickering, which indicates incuriosity about the pre-genocidal conditions in Rwanda, this report was striking for the implicit plot line that it put forth. The report suggested that the democratization process in Rwanda had the potential to move either forwards or backwards-but it did not entertain the possibility that political events might veer off in an entirely different and more sinister direction.

The most explicit warning of the possibility of imminent violence came in a CIA report included in the highly classified National Intelligence Daily of 19 March 1994, less than three weeks before the genocide began. But this paragraph-long warning also focused on the risk of renewed civil war rather than genocide. Under the heading "Rwanda: Threat of Violence Increasing," the paragraph read:

Security is deteriorating in Kigali and in the demilitarized zone between Hutu-dominated government troops and Tutsi rebel forces. Rumors of imminent warfare are sweeping the capital, international relief workers report both sides are fortifying defensive positions in the demilitarized zone, and a nearby American-owned tea factory may close temporarily, according to the US Embassy. Unless President Habyarimana quickly begins a goodfaith effort to form the multiethnic government he agreed to, the rebels probably will resume fighting. ${ }^{45}$

Nor did the State Department's Bureau of Intelligence and Research warn of mass atrocities against civilians - though, during the months leading up to the genocide, it issued increasingly urgent warnings of the risk of a renewed war between the Rwandan government and the Tutsi expatriate army. In December 1993, two months after the assassination of Burundi's first Hutu president, Melchior Ndadaye, INR distributed another classified assessment entitled "Burundi: The Sum of All Fears." This assessment reported that, since October, "Tens of thousands-no one knows exactly how many; estimates range from 30,000 to 150,000-have been killed [and] ... 700,000 persons ... have fled Burundi." Yet the concluding section of this report, entitled "Rwandan spillover," made no reference to the possibility that Rwanda might soon experience violence far exceeding the scope of the bloodshed in Burundi. It declared of Rwanda:

Leaders of the key parties - perhaps reassured by the presence of 800 Belgian and Bangladeshi peacekeepers in the capital, and exhausted from a three-year war that neither the RPF nor government could win-still seem committed to power-sharing. But fear, instability, and disorganization exacerbated by events in Burundi may further delay or derail the establishment of a transition government originally slated to take power in September. ${ }^{46}$

According to the author of this INR report, U.S. diplomats "were paying so much attention to the peace process, and trying to keep it on the rails, trying to get that transitional government going that [the Embassy] didn't really appreciate the possibility of things going completely south." ${ }^{\prime 4}$

\footnotetext{
${ }^{44}$ CIA Directorate of Intelligence, "Africa Review," 14 January 1994, 21, Rwanda Genocide Collection (compiled 19982003), National Security Archive, Washington, DC.

${ }^{45}$ National Intelligence Daily, 19 March 1994, 13, Rwanda Genocide Collection (compiled 1998-2003), National Security Archive, Washington, DC. (Italics in original.)

${ }^{46}$ Bureau of Intelligence and Research, U.S. Department of State, "Burundi: The Sum of All Fears," SC\#12802-93,

December 16, 1993, Rwanda Genocide Collection (compiled 1998-2003), National Security Archive, Washington, DC, 1415. Available from: http://www2.gwu.edu/ nsarchiv/NSAEBB/NSAEBB466/ (accessed 14 January 2016).

${ }^{47}$ U.S. State Department Rwanda analyst, interview with the author, November 2004.
} 


\section{The Perils of Powersharing: U.S. Diplomatic Strategy, 1990-1994}

Peace processes are great. Peace processes sometimes bring peace, and that's wonderful. But peace processes, especially at the U.N. and especially within the State Department, can also be a way of saying we're doing something even when you had, at a minimum, a nagging voice telling you that maybe this ain't working and you have harder decisions to make. -Anthony Lake, U.S. National Security Advisor, 1993-19978

"We were naïve policy optimists, I suppose," says Ambassador David Rawson of the attitude of the U.S. diplomatic corps toward Rwanda during the months leading up to the genocide:

The fact that negotiations can't work is almost not one of the options open to people who care about peace. We were looking for the hopeful signs, not the dark signs.... One of the things I learned and should have already known is that once you launch a process, it takes on its own momentum. I had said, "Let's try this, and then if it doesn't work, we can back away." But bureaucracies don't allow that. Once the Washington side buys into a process, it gets pursued, almost blindly. ${ }^{49}$

The Rwanda analyst in the State Department's Bureau of Intelligence and Research echoes Rawson's view:

I would say the Arusha Agreement, to which we were so committed, was deeply flawed in ways we were probably not willing to admit, because... it was all we had, so we had to make it work.... We had gone down this path to such an extent that... to go back to the international community that had helped forge the peace accord and say, "Well, we better start over again," was just not in the cards. ${ }^{50}$

This commitment to the Arusha process at any price reflected the broader priorities of U.S. foreign policy on Africa in the aftermath of the Cold War. Following the Soviet Union's collapse in the early 1990s, U.S. policymakers had adopted "conflict resolution and democratization" as the watchwords of their diplomacy toward Sub-Saharan Africa. Operating under the premise that democratic societies were intrinsically stable and peaceful, policymakers devised a one-size-fits-all approach to ending violent conflict: convening peace negotiations to produce democratic powersharing agreements, whose implementation should ipso facto result in peace.

This new foreign policy paradigm was summarized by National Security Directive (NSD) 75 on "American Policy Toward Sub-Saharan Africa in the 1990s," which President George H. W. Bush approved in December 1992, and which remained in force during the first years of the Clinton administration. The policy prescriptions set forth in NSD 75 reflected widely shared assumptions of the U.S. foreign policy establishment during the early 1990s: "Post-colonial, authoritarian regimes in Africa have been dismal failures. As they disappear, we have a historical opportunity to show Africans how stability and development can be achieved through participatory political life and responsible government." By propagating "democratic values," the "rule of law," and "free and fair elections," U.S.-sponsored programs could "help make democratic experiments in Africa permanent realities" and thus promote the primary U.S. objectives of "conflict resolution and political stability" in Sub-Saharan Africa. ${ }^{51}$

Despite the lofty rhetoric, the Arusha Accords were a profoundly flawed foundation for stable peace in Rwanda. Astri Suhrke and Bruce Jones describe the Arusha Accords as a "victor's agreement" - or, in the words of Belgian scholar Filip Reyntjens at the time of the signing - "a

\footnotetext{
${ }^{48}$ Lake, Anthony. Frontline interview, 13 December 2003.

${ }^{49}$ Rawson, Amb. David. quoted in Power, A Problem from Hell, 347.

${ }^{50}$ U.S. State Department Rwanda analyst, interview with the author, November 2004.

${ }^{51}$ Bush, President George H. W. National Security Directive 75, "American Policy Toward Sub-Saharan Africa in the 1990s", 2. Available from: https://bush41library.tamu.edu/files/nsd/nsd75.pdf (accessed 14 January 2016).
} 
Levinger

veritable coup d'état for the RPF and the internal opposition." 52 The RPF had routed the Rwandan government's military forces in its February 1993 offensive, and France's military support for the Habyarimana regime had played a critical role in halting the RPF's initial advance toward Kigali. Moreover, the RPF fielded a highly focused and disciplined team of negotiators to the Arusha negotiations of 1992-1993, whereas the government's negotiating team was fractured between Habyarimana's MRND party and three opposition parties. Foreign Minister Boniface Ngulinzira, a member of the opposition MDR, headed the government's negotiating team. On the RPF's insistence, the Hutu extremist Coalition for Defense of the Republic (CDR) was excluded from the negotiating table-but CDR observers attended the Arusha talks and worked to undermine any potential agreement. ${ }^{53}$

Another factor weakening the position of the Rwandan government vis-à-vis the RPF reflected a structural feature of the Arusha negotiations. As INR had emphasized in a classified "African Trends" report issued on 18 September 1992 (nearly a year before the signing of the Arusha Accords):

Habyarimana's side has been pushed harder and more successfully to compromise. The government is vulnerable to military pressure from the RPF and to political and economic pressure from major western donors. The RPF leadership by contrast enjoys sanctuary in Uganda and is not so heavily pressed by Kigali, outsiders, or the costs of a war which is fought on Rwandan soil. It is likely, therefore, that the RPF will maintain a more intransigent negotiating position. This would perpetuate the current instability and stir passions that could lead to the sort of anti-Tutsi genocide that gripped Rwanda and neighboring Burundi in the past. ${ }^{54}$

This report warned of "the possibility of a genocidal civil war" if the ongoing talks in Arusha were to fail:

Whether the parties reach agreement depends partly on how much power President Habyarimana is willing to cede to the RPF and domestic opposition parties. But to be accepted by Kigali (and viewed as legitimate by the Rwandan people), a true settlement also depends on the RPF's willingness to accept a powersharing formula more in accordance with the Tutsis' 10-15 percent of the population than with the 50-50 share the RPF has been demanding.

As a result of these imbalances at the Arusha talks, the final peace agreement was highly unfavorable to Habyarimana's MRND party, which was granted only five of twenty-one cabinet positions in the prospective 22-month Broad-Based Transitional Government (BBTG). The agreement was even less appealing to the extremist CDR, which was excluded from the government altogether. Adding insult to injury, the RPF was given the right to provide 40 percent of the soldiers in the new Rwandan army, and 50 percent of the officer corps, far above the Tutsis' proportion of the country's population..$^{5}$

Suhrke and Jones observe: "While resembling a victor's agreement, the accords left the losing side with access to the state apparatus in an interim period, and hence the means for obstructing the

\footnotetext{
${ }^{52}$ Suhrke and Jones, "Preventive Diplomacy in Rwanda," 244, 246.

${ }^{53}$ Stettenheim, Joel. 2000. "The Arusha Accords and the Failure of International Intervention in Rwanda," in Words over War: Mediation and Arbitration to Prevent Deadly Conflict, Greenberg, Melanie C. John H. Barton, and Margaret E. McGuinness, editors. Lanham, MD: Rowman \& Littlefield, 224-26.

${ }^{54}$ U.S. Department of State, cable State 310659, “INR/AA's African Trends - 9/18/92 (No. 19)," September 23, 1992, in International Decision-Making in the Age of Genocide: Rwanda 1990-1993, Briefing Book, Vol. 1, compiled and produced by the National Security Archive, at George Washington University, June 2014, 1-69. Available from: http://www.ushmm.org/m/ pdfs/20150325-rwanda-briefing-one.pdf (accessed 14 January 2016).

${ }^{55}$ On the proportion of Tutsi in the Rwandan population, see Straus, The Order of Genocide, 19.
} 
implementation of a political order that was decidedly unfavorable to its interests." ${ }^{56}$ Both during the negotiations and in the implementation phase, Habyarimana made no secret of his distaste for the accords. He refused to sign any of the preliminary agreements before the final ceremony in Arusha in August 1993, and he repeatedly disavowed proposals that had been accepted by the government's own negotiating team..$^{57}$ In November 1992, Habyarimana announced in a public speech that the agreement on political power-sharing was "nothing but a scrap of paper...that the government is not obliged to respect." ${ }^{58}$ Several months later, at the 1993 annual conference of the MRND, he pledged to resist any sharing of power with the RPF. ${ }^{59}$

Beyond these general concerns about the political marginalization of the MRND and the CDR's exclusion from power, the Arusha Accords also sparked fears among Rwandan Hutus about their economic well-being and even their physical survival. UN Special Rapporteur B. W. Ndiaye pointed to one of these concerns in his report of August 1993:

Many of the people to whom the Special Rapporteur spoke pointed out that the return of the 400,000 to 500,000 refugees from abroad would cause a number of problems. Firstly, as has been mentioned, Rwanda is the most densely populated country in Africa and there has long since been no land to spare. In addition to this, certain Hutu businessmen are afraid that the Tutsi who have made their fortune in the countries receiving them are coming back to resume control of the Rwandese economy, thereby reasserting their domination..$^{60}$

Assistant Secretary of State for African Affairs Herman Cohen, who oversaw U.S. policy at the outset of the Arusha talks in 1992, had identified the refugee problem as a key obstacle to a peace settlement, and advocated addressing it as a primary issue for negotiation. ${ }^{61}$ But while the final agreement of 1993 guaranteed the right of return for Tutsi refugees, it provided no formal safeguards for the rights of those already residing in Rwanda, apart from the stipulation that "refugees who left the country more than 10 years ago should not reclaim their properties, which might have been occupied by other people." ${ }^{62}$

Another possible cause for concern for the Hutu elites was the loss of the safety net provided by the French military forces in Rwanda, which had intervened three times to protect the regime from the RPF. In January 1993, French Ambassador Georges Martre, who had long been a staunch advocate for the Habyarimana regime, ended his tour of duty in Kigali. ${ }^{63}$ The Arusha Accords mandated that all French military forces leave Rwanda as a precondition for the power-sharing agreement. Their departure in December 1993 deprived Rwandan Hutus of this implicit security guarantee, leaving in place only a weak UN contingent that had neither the mandate nor the capacity for a robust peace enforcement mission.

By far the most damaging blow to the confidence of Rwanda's Hutu leaders was the mass killing that erupted in neighboring Burundi in October 1993, following the assassination of the newly elected Hutu president of Burundi, Melchior Ndadaye. In the words of the State Department's Rwanda analyst:

\footnotetext{
${ }^{56}$ Suhrke and Jones, "Preventive Diplomacy in Rwanda," 244.

${ }^{57}$ See for example U.S. Department of State, cable State 310659, “INR/AA's African Trends - 9/18/92 (No. 19)," 23 September 1992, 1-74.

${ }^{58}$ Stettenheim, "The Arusha Accords," 215; Leader, Rwanda's Struggle for Democracy and Peace, 19.

${ }^{59}$ Keane, Season of Blood, 92.

${ }^{60}$ United Nations Economic and Social Council, "Report by Mr. B. W. Ndiaye, Special Rapporteur," 8.

${ }^{61}$ Stettenheim, “The Arusha Accords," 223.

${ }^{62}$ See Arusha Accords, "Protocol of Agreement between the Government of the Republic of Rwanda and the Rwandese Patriotic Front on the Repatriation of Rwandese Refugees and the Resettlement of Displaced Persons," Article 4, 9 June 1993. Available from: http://www.incore.ulst.ac.uk/services/cds/agreements/pdf/rwan1.pdf (accessed 14 January 2016).

${ }^{63}$ U.S. Department of State, cable Kigali 00068, “Kigali Awaits Protocol," 8 January 1993, Rwanda Genocide Collection (compiled 1998-2003), National Security Archive, Washington, DC.
} 
I think one of the reasons the Rwandan Hutus signed onto Arusha in August was because they felt like they could relax a little bit, because the Tutsis had peacefully surrendered power in [Burundi in] June/July. So the Burundi transition may have contributed to a slight mellowing on the Hutu side. It seemed to be, "okay, this isn't so bad, maybe things are changing, so maybe we can handle this power sharing government." But then the army comes in and assassinates the president and plunges the country into this violent spiral. Rwandans look at that and just think, "Holy Christ, look what's going on down there?"... $[\mathrm{M}]$ oderates were turned into hard-liners, and hardliners were turned into génocidaires, and it was... the only good Tutsi is a dead Tutsi. I don't know if Arusha would have worked under any circumstances, but it became much, much, much more difficult after Burundi went down. ${ }^{64}$

Despite all of these ominous signs, U.S. diplomats continued to view the full and timely implementation of the Arusha Accords as the only viable path to sustainable peace in Rwanda. Joyce Leader, who was the Deputy Chief of Mission at Embassy Kigali, writes that she and other diplomats "assumed, mistakenly as it turned out, that the parties had agreed to ... implement and abide by the agreements reached" and "treat the other side as a legitimate partner." Western diplomatic interventions reinforced the conflict cycle: "The more the violence escalated, the harder we diplomats pushed for implementation of the Arusha Accord."65

During the months leading up to the genocide, only one "Plan B" for Rwanda was seriously discussed by senior U.S. and UN policymakers: namely, "pulling the plug" on UNAMIR and withdrawing the peacekeeping force if the Rwandans failed to establish the transitional government in a timely manner. ${ }^{66}$ Ambassador Donald Steinberg, who was then serving as White House deputy press secretary, points out the fallacy behind this threat. Steinberg observes that telling the parties to the conflict "that if they were being intransigent, we could remove the international peacekeepers" was "the equivalent of saying if there is a babysitter and the kids are misbehaving, the alternative is to have the babysitter leave, and then they burn down the house." 67

\section{Policy Implications for Genocide Prevention}

In a 2006 interview, former President Bill Clinton recalled his own response toward the Rwanda genocide as it was unfolding: "We never even had a staff meeting on it. But I don't blame anybody that works for me. That was my fault. I should have been alert and alive to it." ${ }^{68}$ In seeking to account for the passivity of senior U.S. officials toward the Rwanda genocide, most commentators have pointed to the lack of "political will" for a more robust response. Samantha Power has argued:

It is in the realm of domestic politics that the battle to stop genocide is lost. American political leaders interpret society-wide silence as an indicator of public indifference. They reason that they will incur no costs if the United States remains uninvolved but will face steep risks if they engage. Potential sources of influence-lawmakers on Capitol Hill, editorial boards,

\footnotetext{
${ }^{64}$ State Department Rwanda analyst, interview with the author, November 2004.

${ }^{65}$ Leader, Joyce E. “The Case of Rwanda," unpublished ms., September 2005, 3, 5.

${ }^{66}$ See for example U.S. Department of State, cable USUN 01187, “Discussions on Rwanda Mandate and New SRSG to Zaire", 23 March 1994, Rwanda Genocide Collection (compiled 1998-2003), National Security Archive, Washington, DC. Available from: http://nsarchive.gwu.edu/NSAEBB/NSAEBB472/pdf/us01187.pdf (accessed 14 January 2016). Prudence Bushnell recalls: "I met with both sides in mid-March [1994], about two weeks before the plane was shot down. And I met with Kagame and company, as well as Habyarimana, and Generals. I told them..., 'You have been futzing around on this for a long time, so if you don't put the interim government that you promised to put in place soon, the Security Council may vote to remove the peacekeepers, and if they do, I am really concerned about what may happen.' I think they would have liked nothing better than to have them removed, but I don't know that Habyarimana was in that position. I would understand completely that the extremists would want the peacekeepers out." Interview with the author, September 2006.

${ }^{67}$ Steinberg, Amb. Donald. Interview with the author, 30 October 2006. Steinberg is referring here to his own subsequent negotiating experiences as Ambassador to Angola from 1995 to 1998.

${ }^{68}$ Remnick, David. "The Wanderer," The New Yorker, 18 September 2006.
} 
non-governmental groups, and ordinary constituents - do not generate political pressure sufficient to change the calculus of America's leaders. ${ }^{69}$

Although Power makes a persuasive case, it is important to recognize that genocide cannot be prevented merely by building the political will to do so. In any genocidal situation, popular demands by the American public for humanitarian intervention are likely to arise - if at all - only after mass atrocities have begun, by which time tens or hundreds of thousands of people may already have been killed. And by this stage of the crisis, many low-cost, non-military options for intervention may have evaporated, forcing policymakers to resort to risky and costly peace enforcement missions in order to suppress genocidal violence. From this perspective, it appears that the most important question is not how to generate the political will to respond to genocide when it occurs, but rather how to create the diplomatic capacity to prevent genocide before it begins.

\section{Information Collection and Analysis}

Three principal deficiencies in information collection and analysis hampered U.S. officials' efforts to understand the emerging crisis in Rwanda: (1) the lack of early warning mechanisms for conveying relevant information to high-level U.S. policymakers; (2) inadequate information gathering concerning the conflict; and (3) the distorted framing of the conflict as a civil war rather than as a potential genocide.

Lack of early warning mechanisms. Events in Central Africa rarely attracted the attention of U.S. policymakers above the level of Assistant Secretary of State for African Affairs. Even within the State Department's Africa Bureau, the attention of senior officials was split in numerous directions. Amb. Prudence Bushnell, who was serving as Principal Deputy Assistant Secretary of State for African Affairs, recalls: "I was responsible ...for promoting democracy in 48 countries, resolving conflict in all these countries. It included environment, HIV/AIDS-I mean what a perfectly ridiculous portfolio to have."70 The State Department and intelligence agencies did not have any systematic mechanism for calling the attention of senior officials at the White House and National Security Council to emerging threats of genocide.

Inadequate information gathering. Embassy Kigali was a small overseas post with a staff of only four U.S. nationals including the ambassador. It had no political officer, CIA station, or military attaché, which meant that the ambassador and Deputy Chief of Mission were the primary "eyes and ears" for the mission. Embassy staff cultivated only limited local contacts apart from Rwandan government officials, diplomats from other embassies in Kigali, and foreign nationals working for the U.S. mission. They did not consistently investigate incidents of violence or rumors of treaty violations. Nor did they systematically track or report on "hate radio" broadcasts or speeches by prominent political figures inciting intercommunal violence. Joyce Leader recalls: "I think the formation of the militia was something we knew about, but we just never got out and tried to track it down. We went on what we gathered from other people without any firsthand information. When we would confront people in positions of authority, which we did, they would of course deny that any such militarization was going on."71

Both in Kigali and in Washington, diplomats and intelligence analysts either lacked access to or gave insufficient credence to explicit warnings of potential mass violence. For example, none of our interviewees reported having seen Gen. Dallaire's fax to UN headquarters of 11 January 1994, which warned of the existence of arms caches in Kigali and of Hutu extremists' plans to exterminate the Tutsi. As for the warnings of impending violence issued by Rwandan and international human rights organizations, U.S. diplomats tended to discount these reports, at least partially, as lacking in objectivity and methodological rigor.

Distorted framing of the conflict. The premise that the establishment of democratic institutions was the sole viable path to sustainable peace in Sub-Saharan Africa exerted a powerful influence

\footnotetext{
${ }^{69}$ Power, A Problem from Hell, xviii.

${ }^{70}$ Bushnell, Amb. Prudence. Interview with the author, September 2006.

${ }^{71}$ Leader, Amb. Joyce E. Interview for PBS Frontline documentary, “Ghosts of Rwanda," 30 September 2003. Available from: http://www.pbs.org/wgbh/pages/frontline/shows/ghosts/interviews/leader.html (accessed 14 January 2016).
} 
over U.S. diplomats' and intelligence analysts' reporting on Rwanda. In Joyce Leader's words, "The embassy was of the view that a lot of the violence that was going on in the country [was] random violence. We were of the view that this could be brought under control, if the peace process could be carried [out], concluded, and then implemented."72 Perhaps these episodes of violence appeared "random" because they did not fit observers' expectations for an emerging democracy. Viewed as warning signs of a potential genocide, these same acts of violence might not have appeared random at all.

In an incisive analysis of the UN response to the Rwandan genocide, Michael Barnett observes: "Before policymakers can act, they must come to create a definition and understanding of the situation, and that understanding is mediated by how the institution is organized to think."73 This paper has shown that U.S. foreign policy institutions were not organized to think systematically about the threat of genocide in Rwanda during the early 1990s, and that this deficiency inhibited diplomats' capacity to take effective preventive action. Despite urgent warnings of impending communal violence, U.S. diplomats and intelligence analysts focused principally on the risk of a return to conflict in Rwanda, not on the threat of genocide. Before April 1994, most U.S. intelligence analysts' worst-case scenarios for Rwanda envisioned a potential death toll of tens of thousands, rather than a million. This faulty conflict analysis shaped U.S. policy deliberations, which, in syllogistic fashion, posited "democratization and conflict resolution" as the sole viable path to peace in Rwanda. U.S. policymakers discounted the possibility that the Arusha Accords might aggravate rather than resolve communal tensions in Rwanda, and U.S. officials did not develop any contingency plans for alternative policy options in the event that the power-sharing arrangements mandated by the Accords were to collapse.

To be fair, one must acknowledge that U.S. government and other international observers confronted an exceptionally difficult analytical task during the months leading up to the Rwandan genocide, as well as during the first few weeks after its eruption. In early 1994, there existed a genuine risk of renewed conflict in Rwanda. The downing of the presidential jet on April 6 unleashed three simultaneous catastrophes in the country: a military coup, a civil war, and a genocide. U.S. analysts and policymakers struggled to make sense of these chaotic events. ${ }^{74}$ It is perhaps understandable that, both before and immediately after the outbreak of the genocide, outside observers focused their attention principally on the threat of war. And yet, the failure of American and other international leaders to recognize and respond to the prospect of mass violence against civilians in Rwanda gave an implicit green light to the génocidaires, and may have contributed to expanding the scope of the violence and accelerating its pace.

\section{Policy Formation and Implementation}

At the operational level, the U.S. government was served by a conscientious and capable-though frequently overwhelmed - group of diplomats who implemented its policy toward Rwanda during the three years leading up to the 1994 genocide. The central failure of U.S. diplomacy toward Rwanda during this period stemmed not from the deficiencies of individual diplomats, but rather from the overarching U.S. strategy for conflict resolution in Sub-Saharan Africa. This strategy, as outlined in National Security Directive 75 of 1992, emphasized the adoption and implementation of formal peace agreements and power-sharing arrangements, rather than an incremental approach toward achieving security and mutual trust among competing factions in order to prepare the ground for a stable democratic government.

\footnotetext{
${ }^{72}$ Ibid.

${ }^{73}$ Barnett, Eyewitness to a Genocide, 60.

${ }^{74}$ For example, Pentagon talking points produced on April 11 warned: “Unless both sides can be convinced to return to the peace process, a massive (hundreds of thousands of deaths) bloodbath will ensue that would likely spill over into neighboring Burundi." Despite this stark warning, the talking points stressed that the U.S. was not "willing to get involved... inside Rwanda or Burundi until peace is restored," but that "we would want to restart our security assistance program once the peace process is back on track." Deputy Assistant Secretary of Defense for Middle East Africa, "Memorandum for Under Secretary of Defense for Policy," I-94/16533, April 11, 1994, in International Decision-Making in the Age of Genocide: Rwanda 1990-1993, Briefing Book, Vol. 1, compiled and produced by the National Security Archive, at George Washington University, June 2014, 2-138 and 2-139. Available from: http://www.ushmm.org/m/pdfs/20150325-rwanda-briefing-one.pdf (accessed 14 January 2016)
} 
The U.S. government's policy guidance toward Rwanda offered essentially only two alternatives: "Arusha or bust." Given these constraints, the failure to successfully implement the Arusha Accords would have left U.S. diplomats entirely without options for productive engagement in this crisis. Thus, it is not surprising that the U.S. diplomatic corps invested all its energy into implementing the peace agreement, and discounted the potentially catastrophic effects of the failure to do so.

Yet, perversely, the pressure to implement the Arusha Accords was one of the key factors exacerbating conflict and mutual distrust in Rwanda during the months leading up to the genocide. U.S. diplomats disregarded many ominous signs of the Accords' destabilizing impact on Rwandan politics. For example:

- President Habyarimana's obvious antipathy toward the power-sharing agreement mandated by the Arusha Accords and his reluctance to move toward the Accords' implementation.

- The rage of the Hutu-extremist CDR over its exclusion from the transitional government, and CDR leaders' public incitement of anti-Tutsi violence.

- Population pressures and the ongoing economic crisis, exacerbated by falling global commodity prices and the imposition of an economic austerity program by the International Monetary Fund. These factors heightened fears that the prospective return of hundreds of thousands of Tutsi refugees would threaten the livelihoods of Hutus-both farmers and merchants.

- Above all, the Burundi coup and massacres of civilians in October and November 1993, which terrified Rwandan Hutu leaders about the prospect of sharing political and military power with former Tutsi rebels.

In light of the escalating fears of Rwandan Hutus after the signing of the Arusha Accords, especially after the outbreak of mass violence in neighboring Burundi, the international diplomatic community might have been well-advised to suspend at least temporarily the implementation of the Arusha Accords, and to focus instead on interim steps toward reestablishing physical security and building trust among the rival factions in Rwanda. The report of August 1993 by B. W. Ndiaye, the UN Special Rapporteur, offered a useful starting point for such a policy. Among Ndiaye's recommendations:

- "Mechanism for the protection of civilian populations against massacres. A mechanism for the protection of civilian populations against massacres should immediately be set up, in terms of both prevention ... and monitoring and intervention in cases of violence.... To this end, international teams of human rights observers and a civilian police force might be established, particularly in high-risk areas; with the agreement of the Rwandese authorities, they would be placed under international supervision."

- "National reconciliation campaign. A national reconciliation campaign should be organized in order to attempt to eliminate the negative effects in people's minds of the odious disinformation advocating ethnic and political intolerance, hatred, and violence which has been disseminated in the past. This campaign should begin with a solemn, public commitment, in French and Kinyarwanda, by the Head of State, the Head of Government, the leaders of all the political parties and the religious authorities to adopt a policy of non-discrimination, national unity and respect for human rights..."

- "Media-related action.... The reform of the media should take place in accordance with the spirit of the Declaration on Fundamental Principles concerning the Contribution of the Mass Media to Strengthening Peace and International Understanding, to the Promotion of Human Rights and to Countering Racialism, Apartheid and Incitement to War, proclaimed on 28 November 1978 at the twentieth session of the General Conference of UNESCO."

- "Dismantling of all violent organizations. All violent organizations should be dismantled as a matter of urgency. Criminal organizations such as the 'death squads,' 'Amasasu,' 
or 'Network Zero,' must be identified and dismantled, and their members prosecuted, whatever their rank."

- "Combating impunity and compensating victims.... In describing the need to end the vicious circle of impunity by rendering justice to the victims and their families, some of the people with whom the Special Rapporteur spoke mentioned the need for 'drastic surgery' in order to bring about genuine national reconciliation and eliminate the spectre of a recurrence of the massacres.... History now seems to be repeating itself, and the errors of the past should be avoided." 75

Bruce Jentleson has written: "Foreign policy is about making choices. The choice for preventive diplomacy is politically difficult, the political constraints are serious ones; but they are potentially malleable... The key, as it always has been and always will be, is executive leadership." ${ }^{76}$ As the proposals in Ndiaye's report vividly illustrate, U.S. diplomats were not inevitably locked into the policies that they pursued during the months leading up to the Rwandan genocide. They made choices to adopt one set of policies, aimed at "democratization and conflict resolution," rather than another, that would have sought to build physical security and mutual trust as preconditions for stable democratic rule. ${ }^{77}$ The obstacles to adopting this alternative course of action were not the lack of imagination, nor the lack of knowledge, nor even primarily the lack of resources, because only modest resources would have been required in order to begin to implement several of Ndiaye's proposals. Rather, the obstacles lay principally in the ways that U.S. foreign policy institutions were "organized to think." In order to work effectively to prevent atrocities, diplomats and senior policymakers must learn to think anew about the nature and the urgency of this challenge.

\section{Lessons Learned? The Path Forward}

In the two decades since the Rwandan catastrophe, the U.S. government has adopted measures to better anticipate and respond to emerging threats of genocide and mass atrocities, most notably through President Obama's establishment of the interagency Atrocity Prevention Board (APB) in 2012. This new administrative machinery for atrocities prevention within the U.S. government has facilitated more robust and sustained attention to civil strife in countries of otherwise peripheral interest to senior U.S. policymakers, including Burma, Kenya, Burundi, the Central African Republic, and South Sudan. ${ }^{78}$

The creation of the APB, which convenes on a monthly basis to assess emerging threats of genocide and mass atrocities around the world, has helped remedy some of the institutional deficits that hampered U.S. analysis of the Rwandan crisis on the eve of the genocide. In particular:

- The APB provides an institutional channel for communicating early warnings of potential mass atrocities to the highest levels of the U.S. executive branch.

- When warranted, the APB can provide a limited "surge capacity" for information gathering and analysis concerning emerging threats - though its resources for such activities remain restricted.

- The APB applies an analytical lens focused specifically on the atrocity prevention mandate, allowing it to complement the perspectives of analysts and diplomats who are focused

\footnotetext{
${ }^{75}$ United Nations Economic and Social Council, “Report by Mr. B. W. Ndiaye, Special Rapporteur,” 11 August 1993, 18-22.

${ }^{76}$ Jentleson, Bruce, editor. 1999. Opportunities Missed, Opportunities Seized: Preventive Diplomacy in the Post-Cold War World. Lanham, MD: Rowman \& Littlefield, 348.

${ }^{77}$ For a discussion of this tension between the tasks of democratization and post-conflict stabilization, which some conflict resolution practitioners call the "sequencing dilemma," see for example Durch, William J., editor. 2006. Twenty-firstCentury Peace Operations. Washington, DC: U.S. Institute of Peace, 11-28 and 573-602.

${ }^{78}$ Levinger, Matthew. 2015. "A Core National Security Interest: Framing Atrocities Prevention," Politics and Governance vol. 3, no. 426-27. Available from: http://www.cogitatiopress.com/ojs/index.php/politicsandgovernance/article/view/322 (accessed 14 January 2016); Finkel, James P. 2014. "Atrocity Prevention at the Crossroads: Assessing the President's Atrocity Prevention Board After Two Years," Center for the Prevention of Genocide Occasional Papers, No. 2 (Washington, DC: United States Holocaust Memorial Museum). Available from: http://www.ushmm.org/m/pdfs/20140904-finkel-atrocityprevention-report.pdf (accessed 14 January 2016).
} 
on other national security priorities such as counterterrorism, security cooperation, or democracy promotion. Thus its work can help illuminate the cognitive blind spots that were evident in the U.S. government's analysis of Rwandan politics before the genocide. ${ }^{79}$

Despite this important progress, the broader historical record of recent years-including the commission of mass atrocities across large areas of Africa and the Middle East-suggests that much still remains to be accomplished. Both of the factors that impaired U.S. government officials' understanding of Rwanda in 1993-1994-faulty cognitive framing and rigid policy guidance-have continued to impede U.S. atrocity prevention efforts in recent years.

\section{Faulty Cognitive Framing}

Just as the civil war frame led U.S. officials to underestimate the risk of mass violence against Rwandan civilians in 1994, faulty framing has played a role in shaping U.S. policy toward North Africa and the Middle East since the Arab Spring, as well as toward the newly independent nation of South Sudan. For example, after the fall of Libyan President Muammar Qaddafi in 2011, President Obama and other senior U.S. officials applied a cognitive frame focusing on "democratization" to the Libyan political transition, discounting evidence of growing threats of instability and danger to civilians.

After rebel forces seized control of Tripoli in September 2011, President Obama congratulated the people of Libya on "writing a new chapter in the life of their nation" by building "a future that is free and democratic and prosperous." ${ }^{180} \mathrm{By}$ the following year, prospects for peace and security in Libya had turned bleak. In September 2012, the U.S. Ambassador to Libya was assassinated in Benghazi, and the International Crisis Group warned that Libya was devolving into "a country of regions and localities pulling in different directions, beset by intercommunal strife and where well-armed groups freely roam." ${ }^{81}$ But President Obama remained upbeat. In his speech to the UN General Assembly that month, he declared:

[E]ven as there will be huge challenges to come with a transition to democracy, I am convinced that ultimately government of the people, by the people, and for the people is more likely to bring about the stability, prosperity, and individual opportunity that serve as a basis for peace in our world. So let us remember that this is a season of progress. ${ }^{82}$

With respect to South Sudan, U.S. and other international donors framed the situation principally in terms of the challenges of state-building and "post-conflict reconstruction." Unlike Rwanda, which had attracted meager foreign assistance or high-level diplomatic attention during the early 1990s, the new republic of South Sudan received billions of dollars of aid and intense international scrutiny after achieving independence from Sudan in July 2011. Organizations including the U.S. government, the UN, and international human rights groups closely monitored developments in Sudan and South Sudan, watching for trouble signs in the disputed border territories of Abyei and South Kordofan, in the pastoralist grazing corridors of Jonglei and Unity states, and in other regions.

\footnotetext{
${ }^{79}$ Finkel, "Atrocity Prevention at the Crossroads"; Finkel, James P. 2015. "Moving Beyond the Crossroads: Strengthening the Atrocity Prevention Board," Genocide Studies and Prevention: An International Journal 9, 2: 138-47, available from: http:// scholarcommons.usf.edu/cgi/viewcontent.cgi?article=1361\&context=gsp (accessed 14 January 2016); Alleblas, Tessa and Eamon Aloyo, Sarah Brockmeier, Philipp Rotmann, Jon Western. 2015.“Syria and Beyond: Assessing the Obama Administration's Atrocity Prevention Board," The Hague Institute for Global Justice, unpublished ms.

${ }^{80}$ Obama, Barack. 2011. Remarks by President Obama at United Nations High-Level Meeting on Libya, 20 September. Available from: https://www.whitehouse.gov/the-press-office/2011/09/20/remarks-president-obama-high-level-meetinglibya (accessed 14 January 2016).

${ }^{81}$ International Crisis Group. Divided We Stand: Libya's Enduring Conflicts. Middle East/North Africa Report No. 130, 14 September 2012. Available from: http://www.crisisgroup.org/en/regions/middle-east-north-africa/north-africa/libya/130divided-we-stand-libyas-enduring-conflicts.aspx (accessed 14 January 2016).

${ }^{82}$ Remarks by the President to the UN General Assembly. 25 September 2012. Available from: https://www.whitehouse. gov/the-press-office/2012/09/25/remarks-president-un-general-assembly (accessed 14 January 2016).
} 
Nonetheless, the implosion of the South Sudanese government in December 2013, when a civil war erupted between forces loyal to President Salva Kiir and those loyal to Vice President Riek Machar, took most international observers by surprise. In the words of peacekeeping expert Alison Giffen:

The UN Mission in South Sudan (UNMISS) had focused its protection efforts on early warning, prevention, and support to the government of South Sudan to fulfill the state's responsibility to protect its people. But while Security Council members backed this strategy, they didn't adequately invest in its success through coordinated pressure on the government of South Sudan to make reforms that could have prevented this crisis. This approach to protecting civilians turned out to be foolishly idealistic and wholly inadequate when government forces turned against their own citizens, opposition and irregular forces rose up to join in the abuses, and communities committed crimes against their neighbors. ${ }^{83}$

A study on U.S. atrocity prevention efforts since 2011 found analogous shortcomings in the U.S. government's analytical work on this crisis: "The APB and others had devoted considerable time over the months preceding the current political crisis to the potential threat of atrocities in South Sudan, but focused on Jonglei State and elsewhere where there was inter-ethnic violence rather than on Juba itself." 84

In both of these cases, international policymakers fell prey to the same type of cognitive failures that had characterized the response to the Rwandan genocide. After the defeat and killing of Qaddafi in 2011, the Libyan civil war was lauded as a successful "transition to democracy." President Obama and other international leaders disregarded signs of the country's political unraveling and growing civilian insecurity. After South Sudan achieved its independence, the UN and other international donors oriented their policies around the objectives of state-building and "post-conflict reconstruction." They paid little heed to the possibility that the country's leaderswho had for decades fought in militias against, as well as alongside, each other-might take up arms in a new civil war.

\section{Rigid Policy Guidance}

In cases of faulty cognitive framing, the inability to see a situation clearly can inhibit one's ability to act effectively to address it. Rigid policy guidance can contribute to the converse phenomenon: the unwillingness to act can render one unable to see. In 2006, President Bill Clinton belatedly acknowledged that he had not been "alive" to events in Rwanda during the genocide. Because Clinton had ruled out supporting an international intervention to stop the violence, officials in his administration shied away from discussing the events in Rwanda too precisely - for example by avoiding public use of the word "genocide."

This same tone of studied evasion may be found in some of President Obama's pronouncements on recent crises in North Africa and the Middle East. Obama came into office determined to end his predecessor's wars in the Middle East and Asia, not to begin new ones. Perhaps unsurprisingly, when discussing situations in which he has decided not to intervene, he has steered clear of using language that would imply the need for vigorous American action. Thus, in September 2012, he saw a "season of progress" in Libya, even as other observers saw a nation on the brink of chaos.

With respect to the Syrian civil war, this pattern has been even more striking. At the rare moments when Obama has advocated a muscular response to the Assad regime's atrocitiesnotably in the wake of its 2013 chemical weapons attacks on Syrian civilians - he has spoken vividly and forcefully about the human suffering in the country. ${ }^{85}$ But apart from his speeches about chemical weapons, Obama publicly discussed the Syrian crisis only five times in speeches

\footnotetext{
${ }^{83}$ Giffen, Alison. 2014. "How the UN Should Handle South Sudan," CNN, February 5. Available from: http:// globalpublicsquare.blogs.cnn.com/2014/02/05/how-the-u-n-should-handle-south-sudan/ (accessed 14 January 2016).

${ }^{84}$ Finkel, "Atrocity Prevention at the Crossroads," 22. See also Alleblas, Aloyo, Brockmeier, Rotmann, and Western, "Assessment of U.S. Atrocity Prevention Efforts," 6.

${ }^{85}$ Levinger, “A Core National Security Interest: Framing Atrocities Prevention," 37.
} 
and presidential statements delivered between April 2011 and August 2014. The longest of these statements was 700 words; most were considerably shorter. For example, in his annual address to the UN General Assembly of September 2011, Obama devoted two paragraphs to discussing Syria. On the same occasion the following year, Obama devoted three paragraphs to the Syrian conflict, declaring that "the regime of Bashar al-Assad must come to an end so that the suffering of the Syrian people can stop and a new dawn can begin." 86

Like the Rwandan genocide, the crises in Libya, South Sudan, and Syria were all intractable conflicts that posed difficult challenges for international policymakers. Even the most robust and enlightened policies would have had no guarantee of success, and might have given rise to perverse unintended consequences. But any effective decision-making process must orient the policy to address the facts on the ground, rather than reengineer the facts to meet the policy prescriptions. In order to achieve any desired change, we must begin by paying attention to the problem. We must be alive to the possibilities, both positive and negative. We must recognize that issues of grand strategy and global security cannot be divorced from the mandate to defend individual human lives.

\section{Acknoweldgements}

I would like to thank the U.S. Holocaust Memorial Museum, where I did the initial research for this paper during my time as Director of the Museum's Academy for Genocide Prevention from 2004 through 2007. Thanks also to Will Ferroggiaro, for his work leading to the declassification of more than 4,000 U.S. government documents related to the Rwandan genocide through Freedom of Information Act requests, as well as to Samuel Eberhart for his research support and to Jim Finkel for his insights into U.S. government policies on mass atrocity prevention.

\section{Bibliography}

Adelman, Howard and Astri Suhrke. 1999. The Path of a Genocide: The Rwanda Crisis from Uganda to Zaire. New Brunswick, NJ: Transaction Publishers.

Albright, Madeleine. 2004. Interview for PBS Frontline documentary, "Ghosts of Rwanda." 25 February. Available from: http://www.pbs.org/wgbh/pages/frontline/shows/ghosts/ interviews/albright.html (accessed 14 January 2016).

Alleblas, Tessa and Eamon Aloyo, Sarah Brockmeier, Philipp Rotmann, Jon Western. 2015. "Syria and Beyond: Assessing the Obama Administration's Atrocity Prevention Board," The Hague Institute for Global Justice. Unpublished ms.

Barnett, Michael N. 2002. Eyewitness to a Genocide: The United Nations and Rwanda. Ithaca: Cornell University Press.

Belgian Foreign Ministry. 1994. Telex \#64, From MINAFET to DELBELONU. 25 February. Available from: https://www.documentcloud.org/documents/1015806-19940225-gob-bsrrtranslation.html\#document/p1/a144308 (accessed 14 January 2016).

Brazeal, Gregory. 2011. "Bureaucracy and the U.S. Response to Mass Atrocity," University of Miami National Security and Armed Conflict Law Review Vol. 57: pages 56-71.

Bush, George H. W. 1992. National Security Directive 75, "American Policy Toward Sub-Saharan Africa in the 1990s." 23 December. Available from: https://bush41library.tamu.edu/files/ nsd/nsd75.pdf (accessed 14 January 2016).

Castonguay, Jacques. 1998. Les casques bleus au Rwanda. Paris: Harmattan.

Clinton, Bill. 1998. "Address to Genocide Survivors at the Airport in Kigali, Rwanda." 25 March. Available from: http://www.cbsnews.com/news/text-of-clintons-rwanda-speech/ (accessed 14 January 2016).

Dallaire, Roméo. 2003. Shake Hands with the Devil: The Failure of Humanity in Rwanda Toronto: Random House Canada.

Des Forges, Alison. 1999. "Leave None to Tell the Story": Genocide in Rwanda. New York: Human Rights Watch.

${ }^{86} \mathrm{Ibid}, 33-37$. 
Durch, William J. ed. 2006. Twenty-first-Century Peace Operations. Washington, DC: U.S. Institute of Peace.

Eriksson, John, Howard Adelman, John Borton, Hanne Christensen, Krishna Kumar, Astri Suhrke, David Tardif-Douglin, Stein Villumstad and Lennart Wohlgemuth. 1996. The International Response to Conflict and Genocide: Lessons from the Rwanda Experience, Synthesis Report. Copenhagen: OECD Steering Committee of the Joint Evaluation of Emergency Assistance to Rwanda, March.

Feil, Scott. Preventing Genocide: How the Early Use of Force Might Have Succeeded in Rwanda. 1998. Carnegie Commission on Preventing Deadly Conflict. New York: Carnegie Corporation of New York.

Finkel, James P. 2014. "Atrocity Prevention at the Crossroads: Assessing the President's Atrocity Prevention Board After Two Years." Center for the Prevention of Genocide Occasional Papers, No. 2. Washington, DC: United States Holocaust Memorial Museum: August. Available from: http://www.ushmm.org/m/pdfs/20140904-finkel-atrocity-prevention-report.pdf (accessed 14 January 2016).

Finkel, James P. 2015. "Moving Beyond the Crossroads: Strengthening the Atrocity Prevention Board," Genocide Studies and Prevention: An International Journal, Vol. 9, No. 2: 138-47. Availablefrom: http://scholarcommons.usf.edu/cgi/viewcontent.cgi?article=1361\&context= gsp (accessed 14 January 2016). http://dx.doi.org/10.5038/1911-9933.9.2.1361

Freyer, Jake, and Emily Willard, editors. 2014. “Sitreps Detail Rwanda's Descent into Genocide 1994: Complete Collection of Peacekeepers' Situation Reports from Rwanda to UN Headquarters in New York," National Security Archive Electronic Briefing Book No. 466. 7 April. Available from: http://www2.gwu.edu/ nsarchiv/NSAEBB/NSAEBB466/ (accessed 14 January 2016).

Giffen, Alison. 2014. "How the UN Should Handle South Sudan." CNN. February 5. Available from: http://globalpublicsquare.blogs.cnn.com/2014/02/05/how-the-u-n-should-handlesouth-sudan/ (accessed 14 January 2016).

Gourevitch, Philip. 1998. We Wish to Inform You that Tomorrow We Will Be Killed with Our Families: Stories from Rwanda. New York: Farrar, Straus, and Giroux.

Grünfeld, Fred, and Anke Huijboom. 2007. The Failure to Prevent Genocide in Rwanda: The Role of Bystanders. Leiden: Koninklijke Brill NV. http://dx.doi.org/10.1163/ej.9789004157811.i-299

Guichaoua, André. 2005. Rwanda 1994: Les politiques du genocide à Butare. Paris: Editions Karthala.

Guichaoua, André, ed. 1995. Les crises politiques au Burundi et au Rwanda (1993-1994). Lille: Université de Lille 1, Diffusion Karthala.

Hilaire, Max. 2015. Waging Peace: The United Nations Security Council and Transnational Armed Conflicts. Berlin: Logos Verlag.

International Crisis Group. 2012. Divided We Stand: Libya's Enduring Conflicts. Middle East/ North Africa Report No. 130. 14 September. Available from: http://www.crisisgroup. org/en/regions/middle-east-north-africa/north-africa/libya/130-divided-we-stand-libyasenduring-conflicts.aspx (accessed 14 January 2016).

Jentleson, Bruce, editor. 1999. Opportunities Missed, Opportunities Seized: Preventive Diplomacy in the Post-Cold War World. Lanham, MD: Rowman \& Littlefield.

Keane, Fergal. 1995. Season of Blood: A Rwandan Journey. London: Viking.

Lake, Anthony. 2003. Interview for PBS Frontline documentary, “Ghosts of Rwanda." 13 December. Available from: http://www.pbs.org/wgbh/pages/frontline/shows/ghosts/interviews/lake. html (accessed 14 January 2016).

Leader, Joyce E. 2001. Rwanda's Struggle for Democracy and Peace, 1991-1994. Washington, D.C.: The Fund for Peace.

Leader, Joyce E. 2003. Interview for PBS Frontline documentary, “Ghosts of Rwanda.” 30 September. Available from: http://www.pbs.org/wgbh/pages/frontline/shows/ghosts/interviews/ leader.html (accessed 14 January 2016).

Leader, Joyce E. 2005. “The Case of Rwanda." Unpublished ms.

Levinger, Matthew. 2015. "A Core National Security Interest: Framing Atrocities Prevention." Politics and Governance vol. 3, no. 4. Available from: http://www.cogitatiopress.com/ojs/ index.php/politicsandgovernance/article/view/322 (accessed 14 January 2016). 
Lynch, Colum. 2015. “Exclusive: Rwanda Revisited." Foreign Policy, 5 April. Available from: http:// foreignpolicy.com/2015/04/05/rwanda-revisited-genocide-united-states-state-department/ (accessed 12 January 2016).

Marchal, Luc. 2001. Rwanda: La descente aux enfers: témoignage d'un peacekeeper, décembre 1993-avril 1994. Brussels: Editions Labor.

Melvern, Linda. 2000. A People Betrayed: The Role of the West in Rwanda's Genocide. London: Zed Books. Melvern, Linda. 2004. Conspiracy to Murder: The Rwandan Genocide. London: Verso.

Mission d'information sur le Rwanda. 1998. Rapport d'information sur les opérations militaires menées par la France, d'autres pays et l'ONU au Rwanda entre 1990 et 1994. Available from: http:// www.assemblee-nationale.fr/dossiers/rwanda/r1271.asp (accessed 14 January 2016).

National Security Archive. 2014. International Decision-Making in the Age of Genocide: Rwanda 19901993, Briefing Book, Vol. 1. Washington, DC: George Washington University, June. Available from: http://www.ushmm.org/m/pdfs/20150325-rwanda-briefing-one.pdf (accessed 14 January 2016).

Obama, Barack. 2011. "Remarks by President Obama at United Nations High-Level Meeting on Libya." 20 September. Available from: https://www.whitehouse.gov/the-pressoffice/2011/09/20/remarks-president-obama-high-level-meeting-libya (accessed 14 January 2016).

Obama, Barack. 2012. "Remarks by the President to the UN General Assembly." 25 September. Available from: https://www.whitehouse.gov/the-press-office/2012/09/25/remarkspresident-un-general-assembly (accessed 14 January 2016).

Organization of African Unity International Panel of Eminent Personalities. 2000. Rwanda: The Preventable Genocide. 7 July. Available from: http://www.peaceau.org/en/article/rwandathe-preventable-genocide.

Parliamentary commission of inquiry regarding the events in Rwanda. 1997. Belgian Senate Session of 1997-1998. 6 December. Available from http://www.senate.be/english/rwanda.html (accessed 14 January 2016).

Power, Samantha. 2002. "A Problem from Hell": America and the Age of Genocide. New York: Basic Books.

Prunier, Gérard. 1995. The Rwanda Crisis: History of a Genocide. New York: Columbia University Press. Remnick, David. 2006. "The Wanderer." The New Yorker. 18 September.

International Commission on Human Rights Abuses in Rwanda. 1993. Report of the International Commission on Human Rights Abuses in Rwanda since October 1, 1990. March. Available from: https://www.hrw.org/report/1993/03/01/report-international-commission-investigationhuman-rights-violations-rwanda (accessed 14 January 2016).

Rwanda Genocide Collection. Compiled 1998-2003. National Security Archive, Washington, DC.

Schabas, William A. 2000. Genocide in International Law. Cambridge: Cambridge University Press.

Stettenheim, Joel. 2000. "The Arusha Accords and the Failure of International Intervention in Rwanda." In Words over War: Mediation and Arbitration to Prevent Deadly Conflict. Edited by Melanie C. Greenberg, John H. Barton, and Margaret E. McGuinness, pages 213-236. Lanham, MD: Rowman \& Littlefield.

Straus, Scott. 2006. The Order of Genocide: Race, Power, and War in Rwanda. Ithaca: Cornell University Press.

Suhrke, Astri, and Bruce Jones. 2000. "Preventive Diplomacy in Rwanda: Failure to Act or Failure of Actions?" In Opportunities Missed, Opportunities Seized: Preventive Diplomacy in the Post-Cold War World. Edited by Bruce Jentleson, pages 238-264. Lanham, Md.: Rowman \& Littlefield.

Taleb, Nassim N. 2003. “Rare Events: Why Don't We Understand Them?" Unpublished ms. Highland Forum 23, Las Vegas. November. Available from: http://highlands.vmhost.psu. edu/ reading/docs/blackswan.pdf (accessed 14 January 2016).

United Nations. 1999. Report of The Independent Inquiry into the Actions of the United Nations During the 1994 Genocide in Rwanda and Statement of the Secretary-General on Receiving the Report of the Independent Inquiry into the Actions of the United Nations During the 1994 Genocide in Rwanda. 15 December. Available from: http://www.un.org/Docs/journal/asp/ws.asp?m=S/1999/1257 (accessed 14 January 2016). 
United Nations Economic and Social Council. 1993. Report by Mr. B. W. Ndiaye, Special Rapporteur, on his mission to Rwanda from 8 to 17 April 1993. 11 August (E/CN.4/1994/7/Add. 1).

United Nations Security Council. 1993. Resolution 872. October 5. Available from: http://nsarchive. gwu.edu/NSAEBB/NSAEBB452/docs/doc01.pdf (accessed 14 January 2016).

U.S. Holocaust Memorial Museum. 2014. “The Genocide Fax.” Available from: http://www.ushmm. org/confront-genocide/cases/rwanda/turning-points/genocide-fax-part-i (accessed 14 January 2016).

U.S. Holocaust Memorial Museum. 2014. “Rwanda: Turning Points.” Available from: http://www. ushmm.org/confront-genocide/cases/rwanda/turning-points (accessed 14 January 2016). 